石油技術協会誌 第 72 巻 第 6 号 (平成 19 年 11 月)

JOURNAL OF THE JAPANESE ASSOCIATION FOR PETROLEUM TECHNOLOGY

VOL. 72, NO. 6 (Nov., 2007)

\author{
報告 \\ 貯留層地化学の開発・生産への応用* \\ 加藤 進 ${ }^{* *} \cdot$ 西田 英毅 ${ }^{* * *}$ \\ (Received September 5, 2007 ; accepted November 9, 2007)
}

\title{
Reservoir geochemistry and its application to development and production for petroleum
}

Susumu Kato and Hideki Nishita

\begin{abstract}
Reservoir geochemistry, which studies the compositional variations of petroleum reservoir fluids at a variety of spatial and temporal scales, provides information about details of reservoir filling and leakage, and about petroleum mixing and alteration. This information is useful not only for exploration but also for development and production, and gives us insights not available from other methods.

Our study carried out in the Higashi-niigata gas field clearly shows that reservoir geochemistry using light hydrocarbons is effective for assessing reservoir continuity and charge mixing.

We recommend a routine geochemical analysis of reservoir fluids during production.
\end{abstract}

Key words : reservoir geochemistry, compositional variation, production, Higashi-niigata gas field, reservoir continuity, charge mixing

\section{1. はじめに}

貯留層地化学は 1980 年代後半から発展してきた石油 地化学の一分野であり, 貯留層中の流体（ガス・原油・ 地層水）の不均質性, 特に地化学的性状の変化を検知し, その原因を解明することで, 石油の移動・集積メカニズ ムを理解し，それを石油の探鉱・開発・生産に活用する ことを目的としている (England and Later, 2004)。貯留 層流体が必ずしも均質ではないことは古くから知られて いたが, 貯留層流体の組成変化の原因やその応用につい て言及したのは比較的最近である（例えば, Slenz, 1981; England et al., 1987)。地化学的性状の変化はいろいろな 時間的・空間的スケールで起こっており，そこから貯留 層への石油の充填と逸散, 石油の混合と変質などの情報

* 平成 19 年 6 月 6 日, 平成 19 年度石油技術協会春季講演会 開発・生産部門シンポジウム「油ガス層評価のためのデー 夕の最大活用」で講演 This paper was presented at the 2007 JAPT Development and Production Technology Symposium entitled "Full utilization of various data for better reservoir evaluation" held in Yoyogi, Tokyo, Japan, June 6, 2007.

** 侏地球科学総合研究所 JGI, Inc.

**** 石油資源開発侏技術研究所 JAPEX Research Center

Copyright (C) 2007, JAPT
を得ることが可能である。

本稿では, 主に原油を対象にして, 基礎的な地化学 性状と最近の貯留層地化学の動向を概説し, ケーススタ ディとして東新潟ガス田を取り上げて, 貯留層地化学の 具体的な応用例を述べることにする。

\section{2. 原油の組成と貯留層地化学}

原油は炭化水素を主成分とするが, 硫黄, 酸素, 窒 素をへテロ原子として含有する化合物も含んでいる極め て複雑な混合物である。炭化水素はアルカン（パラフィ ン系炭化水素), シクロアルカン (ナフテン系炭化水素) および芳香族炭化水素からなる（図 1)。

原油の性状は, 根源岩中の有機物の質や熟成度の違い などの生成プロセス, 根源岩や貯留層中での移動・集積 プロセス, トラップに集積した後での変質プロセスなど の多くの要因によって影響を受ける（図 2)。原油－根 源岩対比では, 移動・集積プロセスや変質プロセスの影 響をほとんど受けない成分（例えば，炭素数の大きいス テランなどのバイオマーカー)が利用されている。一方, 貯留層地化学では, 移動・集積プロセスや変質プロセス の影響を受けやすい成分（炭素数の小さいガスや軽質炭 化水素) を利用して, 貯留層の連続性などを検討する (加 


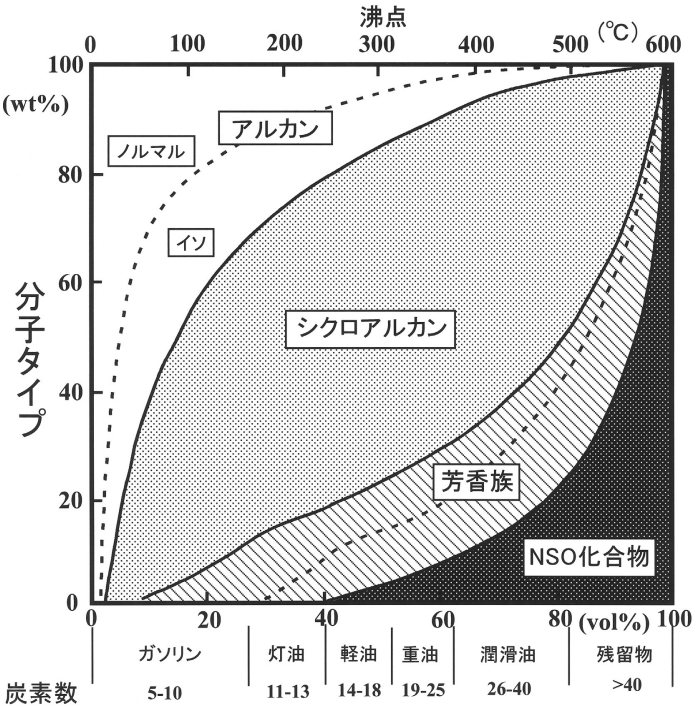

図 1 原油の組成（Hunt（1996） から作成）

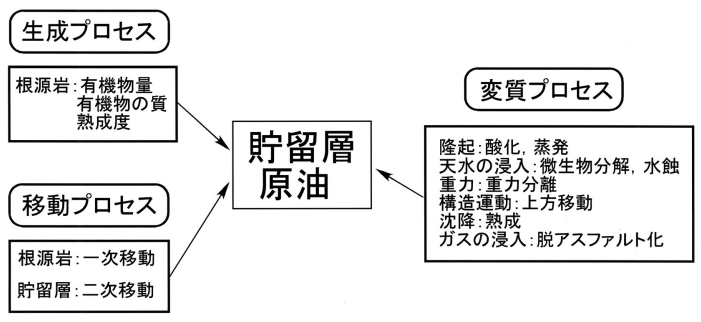

図 2 原油の性状に影響を及ぼす要因 (Blanc and Connan（1993）に基づいて作成)

炭素数

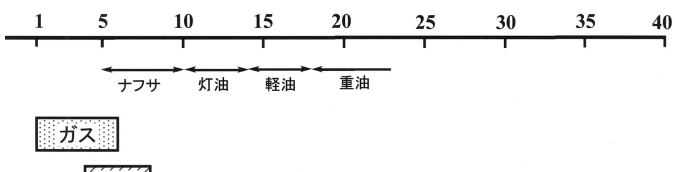

軽質才

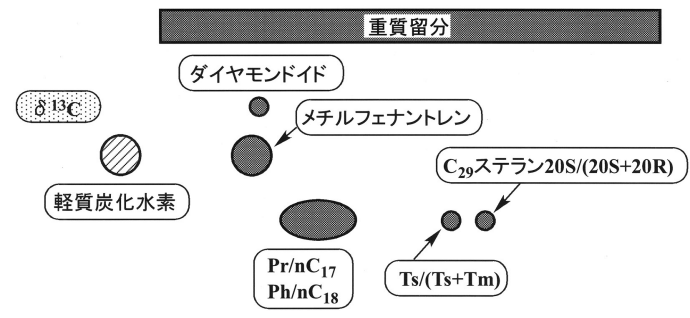

図 3 炭素数と主な熟成度指標

藤, 2002a；図 3)。

最近の貯留層地化学分野のトピックスとして, 原油の 熟成度が用いる熟成度指標によって異なることや, 移動・ 集積は必ずしも一度ではないことを挙げることができる (England and Later, 2004)。原油の熟成度指標の代表的な ものとして以下のものがある。
1） $\mathrm{C}_{29}$ ステランの $20 \mathrm{~S} /(20 \mathrm{~S}+20 \mathrm{R})$ 比

2) $\mathrm{Ts} /(\mathrm{Ts}+\mathrm{Tm})$ 比

3）プリスタン $(\mathrm{Pr}) / \mathrm{nC}_{17}$ 比およびフィタン $(\mathrm{Ph})$ $/ \mathrm{nC}_{18}$ 比

4）芳香族炭化水素のメチルフェナントレン組成： MPI 1 やMPR など

5）軽質炭化水素組成

1）と2）は環状バイオマーカーであり，3）は鎖状バ イオマーカーである。

Wilhelms and Later（2004）によれば，彼らの原油デー タではステラン, メチルフェナントレン, および軽質炭 化水素から推定した熟成度の平均值は, ビトリナイト反 射率（Ro）換算でそれぞれ $0.69 \%, 0.82 \%, 0.97 \%$ であり， 明らかに炭素数の小さい熟成度指標ほど高い熟成度を示 している。このことは, 熟成の進行に伴って生成される 原油が，炭素数の大きい成分から小さい成分へと変化す ることや，生成プロセスが連続的であることと調和的で ある。したがって, 熟成度指標で用いた成分が原油のど の部分を，あるいはどの程度代表しているかを考慮する ことが必要であることを示している。

\section{3. 東新潟ガス田の貯留層地化学}

1959 年（昭和 34 年）に発見された東新潟ガス田には, 西山層から寺泊層にかけて多くのガス層が発達してお り, 椎谷層最上部の $2900 \mathrm{~m}$ 層が主要ガス層である (図 4)。 $2900 \mathrm{~m}$ 層は上位から，2900 mA 層， $2900 \mathrm{mB}$ 層， 2900 $\mathrm{mC}$ 層および $2900 \mathrm{mD}$ 層に細分され, 最上位の $2900 \mathrm{~mA}$ 層にはリングオイルが発達している。1986 年以降, こ のリングオイルを対象に開発井が掘削されており, 現在 MS-46 まで掘削されている。2900 mA 層はさらに上位か ら, $2900 \mathrm{~mA}_{0}, 2900 \mathrm{~mA}, 2900 \mathrm{~mA}_{3}, 2900 \mathrm{~mA}_{4}$ に細分さ れている。この $2900 \mathrm{~mA}$ 層を中心に, 原油の一般性状 (API 比重と硫黄分）および軽質炭化水素組成に基づいて，リ ングオイルの成因やコンパートメント化について検討 した。

3.1 試料, 分析方法およびパラメータ

16 坑井から採取した $2900 \mathrm{~mA}$ 層の原油試料を分析し た。このほかに比較のために，2900 mB 層などから採取 した原油試料も分析した。原油試料は API 比重と硫黄 分を測定した。原油 $100 \mathrm{ml}$ を蒸留し, 沸点 $125^{\circ} \mathrm{C}$ 以下の 軽質留分をガスクロマトグラフ (HP5890B) で分析した。 軽質炭化水素組成では, 平塚 (1976) が提案した, 沸点 が類似した異なる分子タイプの比を用いる 3 つのパラ メータが有用であることが，これまでの経験から分かつ ている（加藤，1993）。これらのパラメータは, 次のよ うに定義されている。 


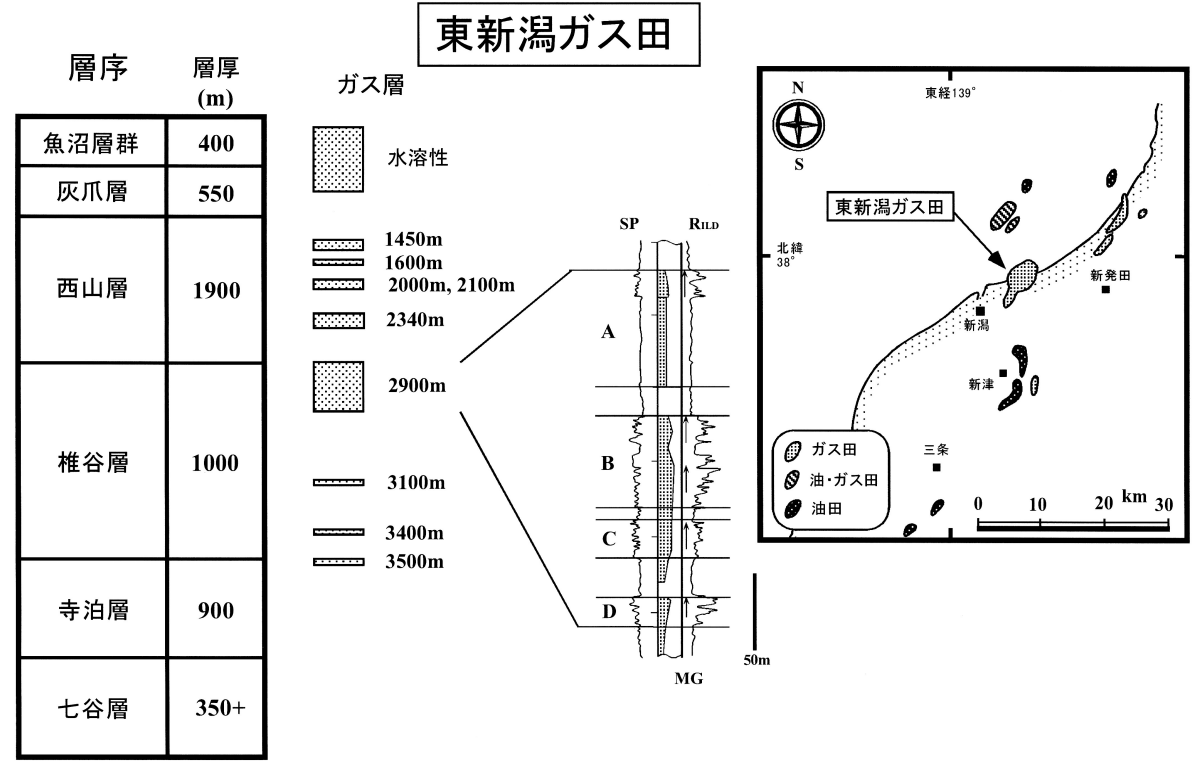

図 4 東新潟ガス田の層序および位置

進化度指数 : $\mathrm{nC}_{7} / 1 \operatorname{tr} 3 \mathrm{DMCP} \quad\left(\right.$ 沸点 : $98 / 92^{\circ} \mathrm{C}$ )

$\mathrm{DMCP}$ : ジメチルシクロペンタン

環境指数：トルエン $/ \mathrm{MCH} \quad\left(110 / 101^{\circ} \mathrm{C}\right)$

$\mathrm{MCH}$ : メチルシクロヘキサン

水蝕度指数 $: 2,3 \mathrm{DMP} / \mathrm{nC}_{7} \quad\left(89 / 98^{\circ} \mathrm{C}\right)$

DMP : ジメチルペンタン

特に, 進化度指数と環境指数のクロスプロットは原油の 熟成度, 微生物分解, 上方移動の推定に有効である（図 5)。

\section{2 分析誤差および試料ごとの誤差}

装置の分析誤差や試料ごとの誤差を検討するために, 同じ試料の繰り返し分析や，ほぼ同時期に採取した試 料の分析結果を表 1 に示す。これらの試料はDST や仕 上げテスト時に採取された試料である。試料によっては API 比重，進化度指数および環境指数がかなりばらつく 場合があり（例えば MS-34，MS-45，MS-46），できる限 り複数の試料を採取・分析することが必要である。

保存試料を同じ坑井，同じガス層から採取した試料 と比較したものを表 2 に示す。油層である NS-4 を除き, いずれも保存試料の API 比重は小さく, 進化度指数や 環境指数も明らかに小さくなっている。API 比重と軽質 留分の割合を見ると（図 6)，ほぼ同じAPI 比重で比較 すると，多くの場合保存試料の軽質留分が少なくなって いる。これは保存期間中に軽質留分が逸散したためと推 定され, 軽質炭化水素組成の検討では, 保存試料の分析 データは利用しないことにする。

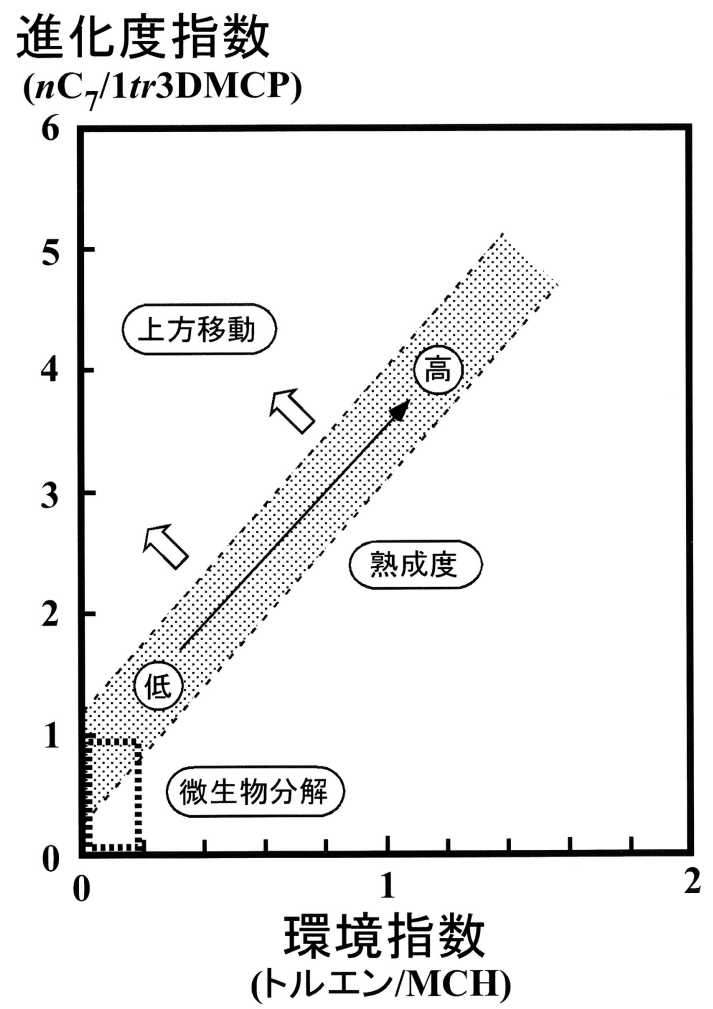

図 5 進化度指数一環境指数プロット

3.3 API 比重と硫黄分

$2900 \mathrm{~mA}$ 層原油のうち, ガス油比が $1,000 \mathrm{~m}^{3} / \mathrm{k} l$ 未満の 油層から産出する原油は軽質原油や中質原油に分類さ 
表 1 繰り返し分析に基づく分析および試料ごとの誤差

\begin{tabular}{|c|c|c|c|c|c|c|c|}
\hline \multirow[t]{2}{*}{ 坑井名 } & \multirow{2}{*}{$\begin{array}{c}\text { 試料 } \\
\text { 番号 } \\
\text { (N) }\end{array}$} & \multirow[t]{2}{*}{ ガス層 } & \multicolumn{2}{|c|}{ 一般性状 } & \multicolumn{3}{|c|}{ 軽質炭化水素組成 } \\
\hline & & & $\begin{array}{c}\text { API 比重 } \\
\text { (度) }\end{array}$ & $\begin{array}{c}\text { 硫黄分 } \\
(w t \%)\end{array}$ & $\begin{array}{c}\text { 進化度 } \\
\text { 指数 }\end{array}$ & $\begin{array}{l}\text { 環境 } \\
\text { 指数 }\end{array}$ & $\begin{array}{c}\text { 水蝕度 } \\
\text { 指数 }\end{array}$ \\
\hline \multicolumn{8}{|l|}{ 東新潟 } \\
\hline \multirow[t]{2}{*}{ MS-34 } & 323 & $2900 \mathrm{~mA}_{4}$ & 49.7 & 0.05 & 2.98 & 0.57 & 0.11 \\
\hline & 324 & & 54.0 & 0.04 & 3.16 & 0.73 & 0.10 \\
\hline \multirow[t]{4}{*}{ MS-41a } & 482 & $2900 \mathrm{~mA}_{4}$ & 37.7 & 0.19 & 1.93 & 0.32 & 0.17 \\
\hline & 483 & & 38.0 & 0.20 & 1.94 & 0.32 & 0.17 \\
\hline & 484 & $2900 \mathrm{~mA}$ & 49.0 & 0.08 & 2.47 & 0.40 & 0.14 \\
\hline & 485 & & 49.9 & 0.08 & 2.47 & 0.39 & 0.15 \\
\hline \multirow[t]{2}{*}{ MS-43 } & 523 & $2900 \mathrm{~mA}_{3}$ & 39.5 & 0.16 & 2.29 & 0.44 & 0.15 \\
\hline & 524 & & 39.1 & 0.16 & 2.21 & 0.43 & 0.15 \\
\hline \multirow[t]{2}{*}{ MS- $44^{*}$} & 542 & $2900 \mathrm{~mA}$ & 39.0 & 0.16 & 2.03 & 0.33 & 0.17 \\
\hline & 542 & & & & 2.06 & 0.33 & 0.16 \\
\hline \multirow[t]{4}{*}{ MS-45 } & 653 & $2900 \mathrm{~mA}_{4}$ & 40.6 & 0.16 & 2.32 & 0.50 & 0.15 \\
\hline & 654 & $2900 \mathrm{~mA}_{4}$ & 38.7 & 0.17 & 2.18 & 0.45 & 0.16 \\
\hline & 655 & $2900 \mathrm{~mA}_{4}+\mathrm{A}$ & 39.0 & 0.16 & 2.23 & 0.47 & 0.15 \\
\hline & 656 & $2900 \mathrm{~mA}$ & 39.0 & 0.16 & 2.23 & 0.48 & 0.15 \\
\hline \multirow[t]{2}{*}{ MS-46 } & 679 & $2900 \mathrm{~mA}$ & 55.2 & 0.03 & 2.76 & 0.56 & 0.13 \\
\hline & 680 & & 59.0 & 0.02 & 2.79 & 0.54 & 0.13 \\
\hline
\end{tabular}

*MS-44 は同じ試料を時間をおいて分析

れ, それらの坑井は構造の北東部に位置している (図 7)。 $2900 \mathrm{~mA}$ 層以深の油・ガス層から採取した原油の API 比 重と硫黄分の関係を図 8 に示す。 $2900 \mathrm{~mA}$ 層以外の原油 の硫黄分は $0.01 \sim 0.02 \mathrm{wt} \%$ であるのに対し， $2900 \mathrm{~mA}$ 層の原油の硫黄分は大きく変化しており, API 比重が小 さくなると増加する明膫な傾向が認められ，これは熟成 度の違いを反映していると考えられる。

\section{4 進化度指数と環境指数}

原油の進化度指数と環境指数との間には正相関が認め られ（図 9), 熟成度の違いを反映していると推定される。 $2900 \mathrm{mB}$ 層の原油は右上に比較的集中しており，その中 には $2900 \mathrm{~mA}$ 層や $2900 \mathrm{mC}$ 層, $2900 \mathrm{mD}$ 層の一部の原油 も入っている。これに対し， $2900 \mathrm{~mA}$ 層の原油は大きく 分散しており, 原油の熟成度が大きく変化していること を示唆している。

$2900 \mathrm{~mA}$ 層の原油を詳しくみると, 多くの場合坑井ご とにほほ同じ位置にプロットされており，油層はガス層 に比べ熟成度が低い（図 9)。しかし，MS-41a では 2900 $\mathrm{mA}$ と $2900 \mathrm{~mA}_{4}$ の原油は明らかに異なった位置にプロッ トされており，これらが別プールであることを示唆して
いる。一方, MS-43 と MS-45 では, $2900 \mathrm{~mA}$ と $2900 \mathrm{~mA}_{4}$ あるいは $2900 \mathrm{~mA}_{3}, \mathrm{~A}_{4}$ の原油はほぼ同じ位置にプロッ トされており，これらが同じプールであるか，あるいは 導通していることを示唆している。

\section{5 進化度指数之 API 比重}

原油の熟成度指標であり, 軽質留分とバルクの異なる 部分を代表している進化度指数と, API 比重のクロスプ ロットを図 10 に示す。ほとんどの原油は API 比重が大 きくなるとともに進化度指数が増加しており, その右上 の端に $2900 \mathrm{mB}$ 層の原油を中心とするグループが位置し ている。このグループに対し， $2900 \mathrm{mD}$ 層やより下位の ガス層の原油は進化度指数が大きく, API 比重が小さい 傾向が認められる。この API 比重の減少は芳香族炭化 水素の割合が増加するためと推定される。また, このプ ロットでは $2900 \mathrm{mD}$ 層の原油が 2 つのグループに分か れているが, 同じことは進化度指数と環境指数のプロッ 卜（図 9）でも認められることから，2900 mD 層は $2 つ$ のプールに分かれていると推定されるが，このことは圧 カデー夕からも支持されている (加藤，2002b)。

$2900 \mathrm{~mA}$ 層の原油を詳しくみると, 幾つかのグループ 
表 2 長期間の試料保存の影響

\begin{tabular}{|c|c|c|c|c|c|c|c|}
\hline \multirow[t]{2}{*}{ 坑井名 } & \multirow{2}{*}{$\begin{array}{c}\text { 試料 } \\
\text { 番号 } \\
(\mathrm{N}) \\
\end{array}$} & \multirow[t]{2}{*}{ ガス層 } & \multicolumn{2}{|c|}{ 一般性状 } & \multicolumn{3}{|c|}{ 軽質炭化水素組成 } \\
\hline & & & $\begin{array}{c}\text { API 比重 } \\
\text { (度) }\end{array}$ & $\begin{array}{l}\text { 硫黄分 } \\
(\mathrm{wt} \%) \\
\end{array}$ & $\begin{array}{l}\text { 進化度 } \\
\text { 指数 }\end{array}$ & $\begin{array}{l}\text { 環境 } \\
\text { 指数 }\end{array}$ & $\begin{array}{l}\text { 水蝕度 } \\
\text { 指数 }\end{array}$ \\
\hline \multicolumn{8}{|l|}{ 東新潟 } \\
\hline \multirow{2}{*}{ NS-4 } & 052 & $2340 \mathrm{~m}$ & 44.3 & 0.09 & 2.94 & 0.70 & 0.13 \\
\hline & 432 & & 43.4 & 0.11 & 3.01 & 0.74 & 0.13 \\
\hline \multirow[t]{2}{*}{ NS-6 } & 051 & $2900 \mathrm{mB}$ & 51.4 & 0.02 & 3.10 & 0.65 & 0.13 \\
\hline & 458 & & 55.2 & 0.02 & 3.37 & 0.92 & 0.12 \\
\hline \multirow[t]{4}{*}{ NS-13 } & 043 & $2900 \mathrm{mB}$ & 41.4 & 0.05 & 2.73 & 0.24 & 0.20 \\
\hline & 439 & & 57.4 & 0.02 & 3.44 & 1.01 & 0.12 \\
\hline & 044 & $2900 \mathrm{mD}$ & 40.6 & 0.07 & 2.58 & 0.20 & 0.21 \\
\hline & 521 & & 51.8 & 0.01 & 3.69 & 0.98 & 0.11 \\
\hline \multirow[t]{3}{*}{ NS-16 } & 047 & $2900 \mathrm{mC}$ or $\mathrm{D}$ & 53.9 & 0.01 & 3.20 & 0.76 & 0.13 \\
\hline & 433 & $2900 \mathrm{mC}(+\mathrm{D})$ & 56.2 & 0.01 & 3.38 & 0.91 & 0.12 \\
\hline & 434 & $2900 \mathrm{mD}(+\mathrm{C})$ & 55.6 & 0.02 & 3.38 & 0.94 & 0.12 \\
\hline \multirow[t]{2}{*}{ NS-10 } & 050 & $3100 \mathrm{~m}$ & 50.9 & 0.04 & 3.22 & 0.92 & 0.13 \\
\hline & 451 & & 45.1 & 0.02 & 3.92 & 1.14 & 0.10 \\
\hline
\end{tabular}

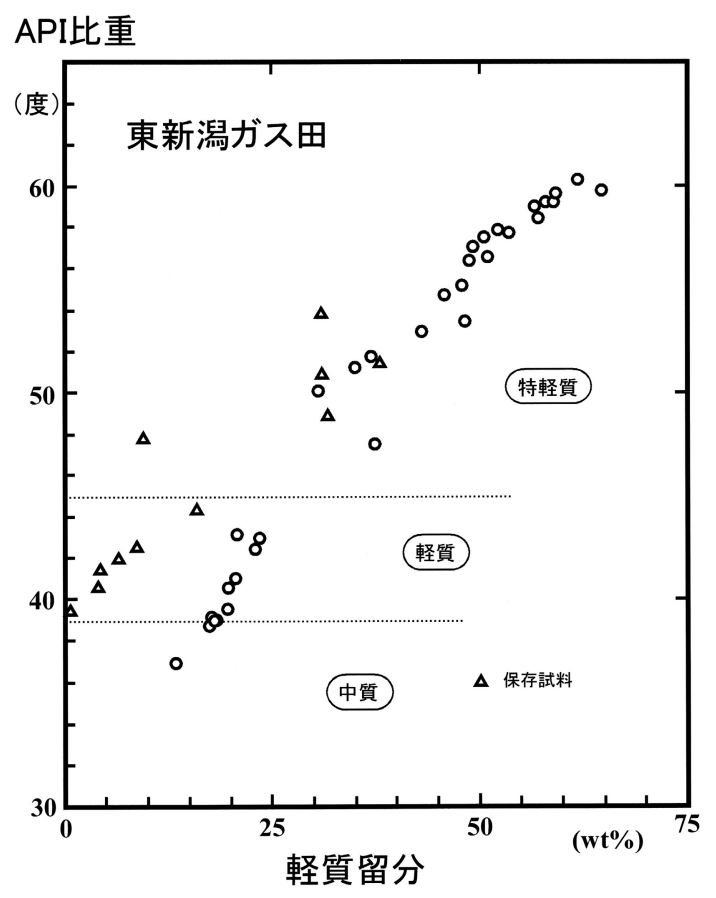

図 6 API 比重と軽質留分の関係

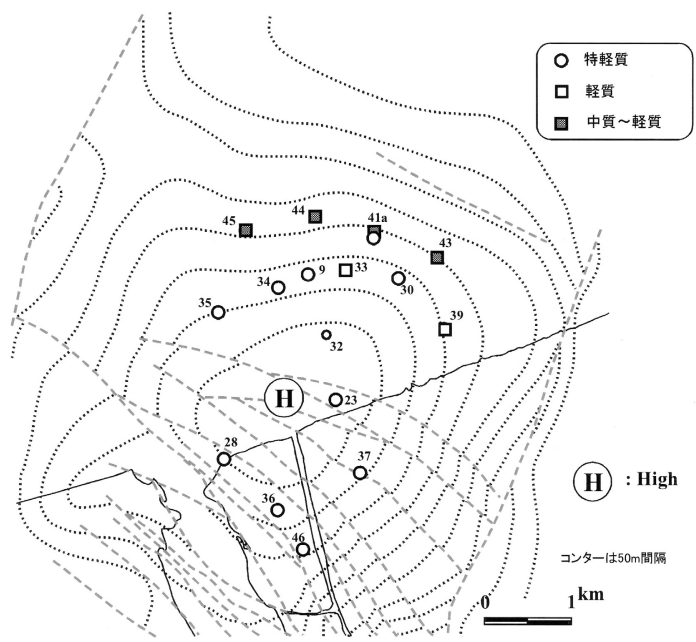

図 7 軽質・中質原油の分布

に細分できる。油層はひとつのトレンドを有しているが, MS-41a, MS-44, MS-43, MS-45 と MS-33, MS-39 の 2 つ のサブグループ (D1, D2) に細分される。ガス層は少な くとも 3 つのグループに分かれ，それらは MS-41a（2900 mA）のみ (C), MS-30, MS-28, MS-34, MS-35 のグルー プ $(\mathrm{B})$ ，そしてその他のグループ $(\mathrm{A})$ である。これら 


\section{API比重}

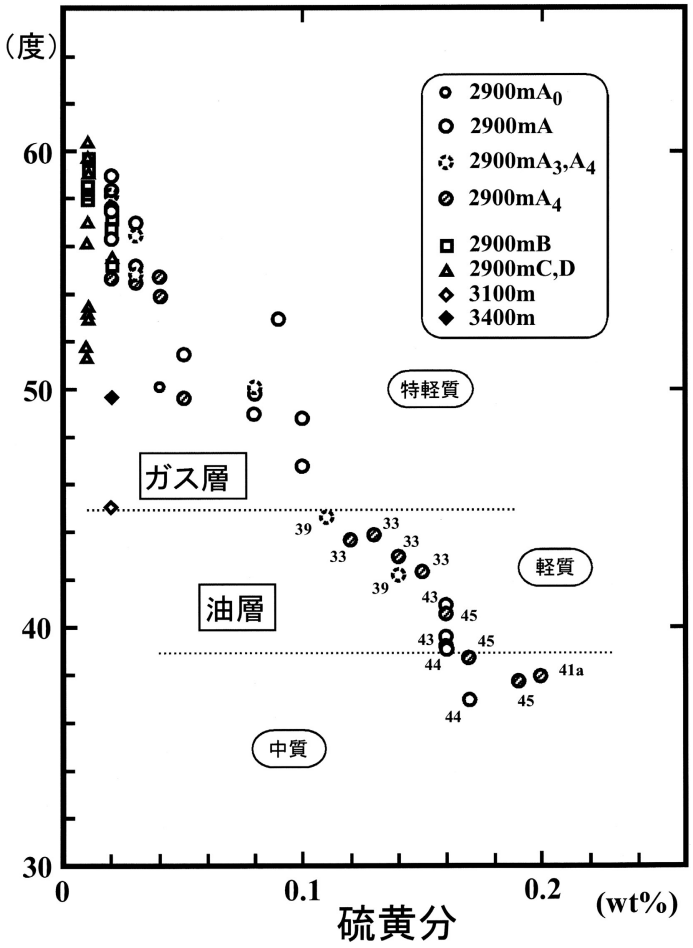

図 8 東新潟ガス田における原油の API 比重と硫黄 分の関係

の平面的な分布を図 11 に示す。 D2 が北側に分布し，A が南を中心に北へ伸び，その周りに B や D1，Cが分布 している。このような分布は，北方から移動してきた熟 成度の低い油と, 深部から移動してきた熟成度の高いガ ス（コンデンセート）の混合で説明できる。このことは ガスのメタンの炭素同位体組成 $\left(\delta{ }^{13} \mathrm{C}_{1}\right)$ の分布からも 支持される（加藤，2002b)。

\section{6 生産に伴う組成変化}

同じ坑井の同じ貯留層から, 繰り返し試料を採取・分 析することによって，生産に伴って原油の組成がどのよ うに変化するかを把握することができるが，まだこのよ うな報告はほとんど見かけない。進化度指数と環境指数 の生産に伴う変化をみると, 生産に伴って両指数が減少 する傾向は認められるようであるが，必ずしもすべての 坑井で同じ傾向とは言えない（図 12）。今後, さらにデー タの蓄積が必要である。

\section{7 まとめ}

原油の貯留層地化学から明らかになったことを整理す ると,以下のようになる。

（1） $2900 \mathrm{~mA}$ 層

・ MS-41a では $2900 \mathrm{~mA}$ と $2900 \mathrm{~mA}_{4}$ の原油は異なってお

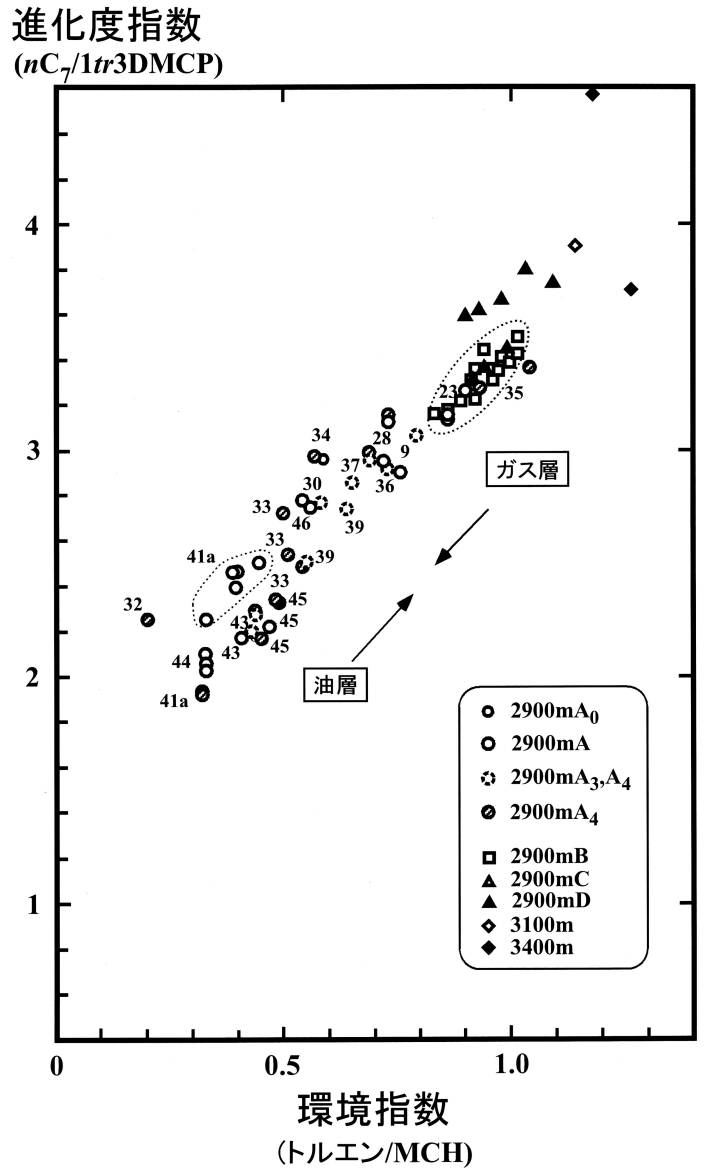

図 9 東新潟ガス田における原油の進化度指数と環 境指数の関係

り，これらは別プールである可能性が高い。

・ MS-43, MS-45 では $2900 \mathrm{~mA}$ と $2900 \mathrm{~mA}_{4}$ あるいは $2900 \mathrm{~mA}_{3}, \mathrm{~A}_{4}$ は同じ原油であり, これらは同じプー ルであるか，あるいは導通していると推定される。

- 大きな組成変化は, 北方より移動してきた熟成度の低 い油が, 深部から移動してきたガス（コンデンセート） と混合しているためと推定される。

（2） $2900 \mathrm{mB}$ 層は軽質炭化水素組成が最も均質であり, 1 つのプールであると推定される。

（3） $2900 \mathrm{mD}$ 層は軽質炭化水素組成に違いが認められ ることから，2つのプールからなる可能性が高い。

4. おわりに

原油の軽質炭化水素組成は, 一般性状など他の成分の データも活用することによって, 貯留層の連続性を判定 することに利用することが可能であり，入れ物としての 貯留層ではなく, 周囲の坑井と同じプールであるのかど 


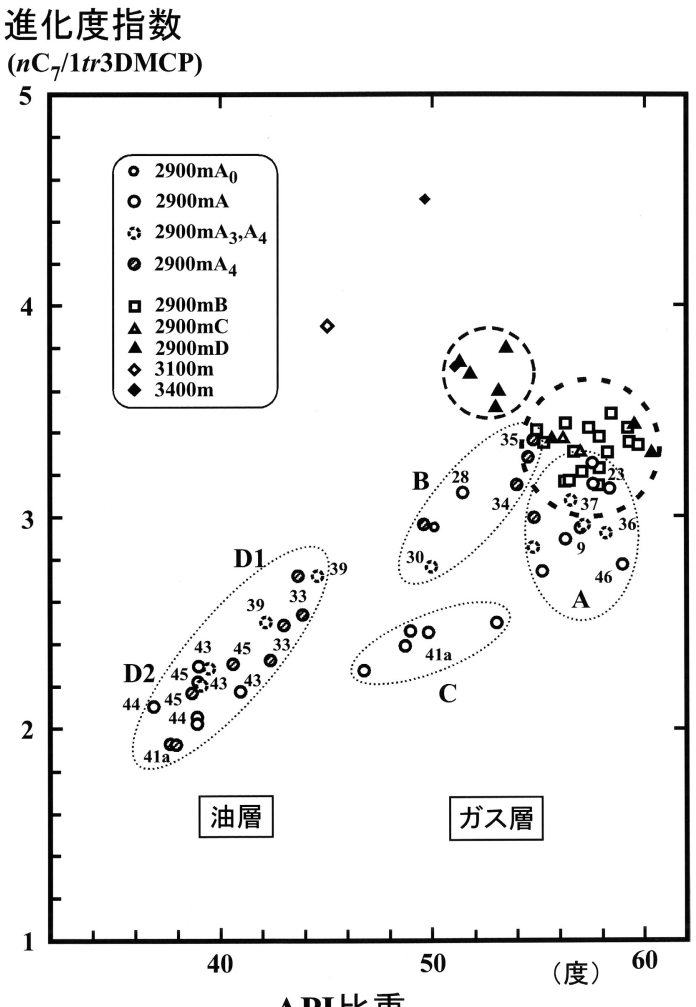

図 10 東新潟ガス田における原油の API 比重と進 化度指数の関係

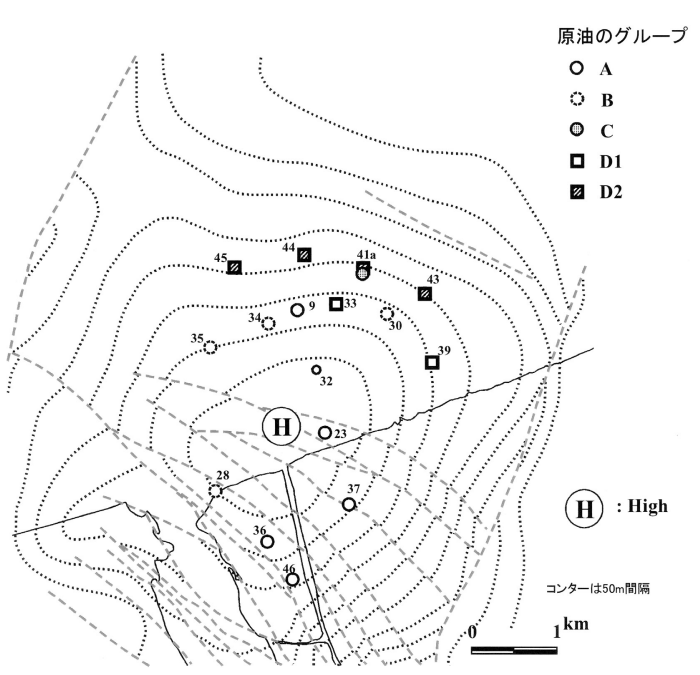

図 $112900 \mathrm{~mA}$ 層の原油グループの平面的な分布

うかという流体そのものの坑井対比や，DSTなどのテ ス卜時の評価，例えば複数の貯留層がある場合にはそれ らがひとつのプールであるのかどうかなどを判定するこ とに役立つであろう。また, 生産に伴う軽質炭化水素組

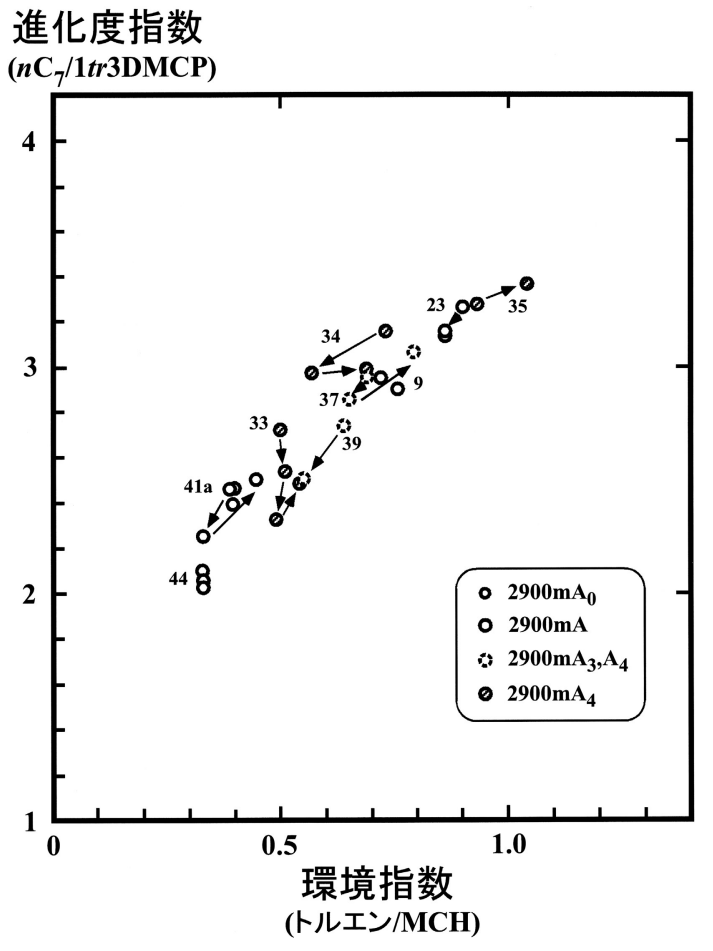

図 12 生産に伴う進化度指数と環境指数の変化

成の変化は，モニタリングツールとして利用できる可能 性もある。

東新潟ガス田の例では, 原油の一般性状と軽質炭化水 素組成に的を絞って述べたが, ガスの炭素同位体組成も 非常に有益なデー夕を提供している（加藤, 2002b ; 早 稲田・岩野, 2007)。地下の貯留層の状況は直接観察す ることは難しいので，できるだけ多くの間接的なデー夕 を取得して, 貯留層を総合的に解析することが重要であ る。したがって, テスト時の流体試料の採取・地化学分 析は当然実施すべきであるが, 坑底圧測定などと同様に, 定期的な流体試料の採取・地化学分析をルーチンとして 実施することを強く推奨したい。

謝 辞

資料の公表を許可された石油資源開発株式会社および 三菱ガス化学株式会社に深謝します。東新潟ガス田の貯 留層地化学は, 平成 11 年度に石油公団 (現独立行政法 人石油天然ガス・金属鉱物資源機構）石油開発技術セン ターの委託研究として実施した成果を基に, 最近の掘削 成果を加えて再検討した。石油資源開発株技術研究所に おいて, 原油やガスの地化学分析を担当している加藤恵 悦, 早稲田 周, 岩野裕継の各社員, 東新潟ガス田の貯 留層について教えていただいた同社開発本部金子賢嗣社 
員に感謝します。

\section{引用 文 献}

Blanc, Ph. and Connan, J., 1993 : Crude oils in reservoirs : the factors influencing their composition. Applied Petroleum Geochemistry, 151-172.

England, W. A. and Larter, S., 2004 : Introduction. In Cubitt, J. M., England, W. A. and Larter, S. eds. : Understanding Petroleum Reservoirs : towards an Integrated Reservoir Engneering and Geochemical Approach, Geological Society, London, Special Publications, 237, 1-5.

England, W. A., Mackenzie, A. S., Mann, D. M. and Quigley, T. M., 1987 : The movement and entrapment of petroleum fluids in the subsurface. Jour. Geol. Soc. London, 144, 327 347.

Hunt, J. M., 1996 : Petroleum Geochemistry and Geology (2nd ed.). 39, W. H. Freeman.

平塚隆治, 1976 : 石油の生成および進化の地化学的考 察一後報 油の進化, 変質一。石技誌, 41(6)，338-
350.

加藤 進, 1993 : 本邦の油・コンデンセートの軽質炭化 水素組成. 石技誌, 58(3)，209-217.

加藤 進, 2002a：貯留層地化学. 石技誌， $67(2) ， 240-$ 245.

加藤 進, 2002b : ガス層の貯留層地化学. 天然ガス 2002, No. 6, 14-24.

Slenz, L. W., 1981 : Geochemistry of reservoir fluids as a unique approach to optimum reservoir management. SPE Middle East Technical Conference, Paper 9582, 37-50.

Wilhelms, A. and Larter, S., 2004 : Shaken but not always stirred. Impact of petroleum charge mixing on reservoir geochemistry. In Cubitt, J. M., England, W. A. and Larter, S. eds. : Understanding Petroleum Reservoirs : towards an Integrated Reservoir Engneering and Geochemical Approach, Geological Society, London, Special Publications, $237,27-35$.

早稲田 周・岩野 裕継, 2007 : ガス炭素同位体組成に よる貯留層評価．石技誌， 72(6)，585-593. 